\title{
Induction of Polyphenol Oxidase in Walnut and Its Relationship to the Pathogenic Response to Bacterial Blight
}

\author{
Fatemeh Khodadadi \\ Department of Plant Pathology, University of Shahid Bahonar, Kerman, Iran
}

Masoud Tohidfar

Department of Biotechnology, Faculty of New Technologies and Energy Engineering, Shahid

Beheshti University, G. C. Tehran, Iran

Mehdi Mohayeji

Department of Agronomy and Plant Breeding, University of Shahid Bahonar, Kerman, Iran

Abhaya M. Dandekar and Charles A. Leslie

Department of Plant Science, University of California, Davis, CA 95616

Daniel A. Kluepfel

Department of Plant Pathology, University of California, Davis, CA 95616

Timothy Butterfield

Department of Plant Science, University of California, Davis, CA 95616

\section{Kourosh Vahdati ${ }^{1}$ \\ Department of Horticulture, University of Tehran, College of Aburaihan, Tehran, Iran}

\begin{abstract}
AdDITIONAL INDEX wORDs. Juglans regia, pathogenesis related protein, phenolic compounds, Xanthomonas arboricola pv. juglandis

Abstract. Plants respond to pathogens with both active and passive defense mechanisms. These defense responses include the induction of defense or defense-related genes such as polyphenol oxidase (PPO) and pathogenesis-related (PR) proteins. The role of PPO in the interaction between bacterial blight [Xanthomonas arboricola pv. juglandis (Xaj)] and walnut (Juglans regia) was studied. JrPPO-1 and P14a genes were identified in two walnut cultivars, Chandler and Serr, using standard polymerase chain reaction (PCR) to understand their inducible ability in response to $X a j$. 'Serr' and 'Chandler' were inoculated with $X a j$ strain 417 . PPO activity in leaves was assayed at $0,24,72,96$, 120, and 144 hours after inoculation. Results showed a steady increase in activity commencing within 24 hours of inoculation. Increase in PPO activity was close to 2 -fold greater in 'Chandler' than in 'Serr' at all time points examined. Real-time PCR analysis showed differences between cultivars in PPO gene expression. The $\mathrm{JPPO}-1$ gene was highly expressed in both cultivars 24 hours after inoculation but expression in 'Serr' was much greater than in 'Chandler'. Significant expression of P14a gene was observed in both cultivars within 24 hours. Expression in 'Serr' was strong and maximized with a significant increase at 96 hours. Expression in 'Chandler' was far weaker than 'Serr' at 24 hours and did not increase further. Our results imply that the walnut-bacterial blight interaction induces the expression of $\mathrm{JPPO}-1$ and P14a as well as the activity of PPO.
\end{abstract}

Plants regulate a complex array of responses to environmental factors such as physical, chemical, and biological stresses. These general responses include basal resistance, hypersensitive response (Heath, 2000), and systemic acquired resistance [SAR (Ward et al., 1991)]. In addition, in plantpathogen interactions, different mechanisms are activated such as PPOs, antimicrobial agents, and PR proteins. PPOs are a group of copper-containing enzymes that are able to catalyze the oxidation of $o$-diphenol compounds to quinones (Steffens et al., 1994). In spite of their well-defined role in ultraviolet

Received for publication 28 Oct. 2015. Accepted for publication 14 Dec. 2015. We thank the University of Tehran, the Iran National Science Foundation (INSF), the University of California, Davis, and the University of Shahid Bahonar, Kerman, for their support.

${ }^{1}$ Corresponding author. E-mail: kvahdati@ut.ac.ir. protection in animals, the physiological role of PPOs in plants has remained unclear and most studies have focused on the postharvest browning reactions observed in cut fruits and vegetables (Arpita et al., 2010; Walker, 1995). Roles of PPO have been demonstrated in biosynthetic processes (Mesquita and Queiroz, 2013; Mueller et al., 1997; Steiner et al., 1999; Strack et al., 2003), defense against herbivores (Wang and Constabel, 2004a, 2004b), fungal pathogenicity, fungal defense reaction (Jacobson, 2000; Soler-Rivas et al., 2000), and resistance of plant to stress, wounding, pathogenesis, and stressrelated hormones such as methyl jasmonate (MeJA) and salicylic acid (Li and Steffens, 2002; Raj et al., 2006; Thaler et al., 1999; Thipyapong et al., 2004). Until now, no clear report of how PPO might affect pathogens has been presented, but several mechanisms for the effect of PPO on pathogens have been suggested, including the toxicity to pathogens of quinones 
generated by PPO, cross-linking of quinones with phenolic compounds, and proteins that might result in the formation of physical barriers to pathogens attack (Li and Steffens, 2002).

PR proteins are another group of proteins induced by the interaction between plant and pathogen and are biomarkers for the functioning of the inducible plant defense response. Production and accumulation of these proteins in plants are a countermeasure against invading pathogens.

Local accumulation of PR proteins has been shown in infected as well as in surrounding tissues and serves to isolate infected tissues from uninfected tissues. The isolation of uninfected tissue can help localize the infection and prevent systemic spread to the rest of the affected plant (Ryals et al., 1996; van Loon and van Strien, 1999). P14a is a member of the PR-1 family from tomato (Solanum lycopersicum) and the most abundant protein accumulating in tomato leaves in response to plant pathogens (Alexander et al., 1993). This protein has been shown to inhibit programmed cell death and also has been found to accumulate during aging of tomato leaves (Camacho Henriquez and Sanger, 1982). P14a also serves as a molecular marker for SAR response (Ryals et al., 1996).

Many phenolic compounds have been found in walnut (Colaric et al., 2005), some of which have a role in defense against pathogens (Radix et al., 1998; Solar et al., 2006). Therefore, walnut could be used as a model to clarify the roles of PPO. A novel and essential role of PPO in secondary metabolism and as a regulator of cell death in walnut has been recently described (Araji et al., 2014).

Walnut blight, caused by Xaj, is one of the most important diseases of walnut and can cause severe economic loss (Garcin and Duchesne, 2001). Yet, the mechanisms of walnut response to this infection are poorly understood. The relationship between infection of walnut with $X a j$ and expression of the PPO (enzyme activity and gene expression) is a focus of the present study. On the basis of field observation and previous studies, the walnut cultivar Serr is considered very susceptible to $X a j$. Although susceptible, blight generally has been a less serious problem for the cultivar Chandler (Teviotdale et al., 1985; Woeste et al., 1992). For this reason, we chose to work with these two economically important cultivars.

The objective of our study was to determine the relative levels of expression of PPO and P14a transcripts with respect to disease symptoms in the walnut-bacterial blight interaction. Herein, we report PPO enzyme activity in leaves of 'Serr' and 'Chandler' and additionally, JrPPO-1 and PRI gene expressions following $X a j$ infection. The results of this study are potentially important for identifying walnut cultivars resistant to bacterial blight in walnut breeding programs.

\section{Materials and Methods}

Plant materials. Potted plants of two 1-year-old clonal own-rooted walnut cultivars (Chandler and Serr) grown in a greenhouse at the University of California, Davis, CA, were used to determine PPO enzyme activity and expression of JrPPO-1 and P14a genes. Three plants of each cultivar were used as replicates.

BACTERIAL SUSPENSION AND INOCULATION. The $\mathrm{Xaj}$ strain 417 used in this study has been recently described (Pereira et al., 2015). A bacterial suspension $\left(10^{8} \mathrm{cfu} / \mathrm{mL}\right)$ in sterile distilled water was generated from bacterial cultures grown on yeast extract peptone (YEP) medium at $25^{\circ} \mathrm{C}$ for $3 \mathrm{~d}$. Bacterial concentration was adjusted with a spectrometer (absorbance at $600 \mathrm{~nm}=0.2$ ) and confirmed after plating onto YEP dilutions.

Attached whole leaflets were inoculated with the bacterial suspension $\left(10^{8} \mathrm{cfu} / \mathrm{mL}\right)$ using a syringe. Infiltration was achieved by forcing the liquid into the intercellular spaces through the stomates. To determine the PPO activity and expression of the $J r P P O-1$ and $P 14 a$ genes, 18 leaflets in total, six leaflets per replicate of each cultivar (three replications per cultivar), were infiltrated with $10^{8} \mathrm{cfu} / \mathrm{mL}$ of inoculum using a syringe at different sites on each leaflet so that the entire leaflet was covered (Aleta et al., 2001; Topp et al., 1993). Therefore, for each examination such as PPO assay and RNA extraction, three entire infiltrated leaflets were sampled each time. Inoculated plants were incubated in a growth chamber at $28{ }^{\circ} \mathrm{C}$ and relative humidity of more than $90 \%$. Moreover, as a control, the same number of leaves from the different plants was infiltrated with sterile distilled water instead of inoculum (mock inoculated). Triplicate samples were harvested at 0, 24, $72,96,120$, and $144 \mathrm{~h}$ after inoculation from control and inoculated samples (one inoculated leaflet and one control leaflet sampled from each tree on each date).

PPO Assay. Total protein was isolated from the whole leaflet samples detached at $0,24,72,96,120$, and $144 \mathrm{~h}$ after inoculation. Proteins were extracted as described by Escobar et al. (2008) using buffer D [50 mM Tris base $\mathrm{pH} 8.3 ; 1 \%(\mathrm{w} / \mathrm{v})$ PEG 8000 (Sigma-Aldrich, St. Louis, MO); $11 \%$ (v/v) glycerol; $0.015 \%(\mathrm{w} / \mathrm{v})$ citric acid monohydrate; $0.010 \%(\mathrm{w} / \mathrm{v})$ cysteine monohydrate; $0.010 \%(\mathrm{w} / \mathrm{v})$ ascorbic acid] (Escobar et al., 2008). Total protein concentration was determined by Bradford assay (Bradford, 1976) using bovine serum albumin as a protein standard. Spectrophotometric assay for PPO was conducted as described by Constabel and Ryan (1998), using $5 \mathrm{mg} \cdot \mathrm{mL}^{-1}$ L-3,4 dihydroxyphenylalanine (L-Dopa) as a substrate and setting the plate reader at $490 \mathrm{~nm}$ and $30{ }^{\circ} \mathrm{C}$. The assay solution consisted of $100 \mathrm{~mm} \mathrm{NaPO}_{4}(\mathrm{pH} 7), 0.015 \%$ (w/v) sodium dodecyl sulfate, and catalase $(280 \mathrm{U} / \mathrm{mL})$. Negative control activity assays containing $1 \mathrm{~mm}$ kojic acid as a specific PPO inhibitor were performed to validate the specificity of the assay. PPO activity in the presence of kojic acid was also assayed by spectrophotometer at $490 \mathrm{~nm}$ (VERSA Max microplate reader; Molecular Devices, Concord, ON, Canada) using L-Dopa as a phenolic substrate (Constabel and Ryan, 1998).

DNA EXtraction And PCR reaction. Total genomic DNA was extracted from the leaf tissue of two walnut cultivars, Chandler and Serr, using DNeasy Plant Mini Kit (Qiagen, Hilden, Germany). PCR was performed in $25 \mu \mathrm{L}$ reaction mixture consisting of $1 \mathrm{U}$ of Taq DNA polymerase, $250 \mu \mathrm{M}$ of each deoxynucleotide triphosphate, $250 \mathrm{ng}$ DNA templates, and 10 pmol of each primer. PCR was performed for the $P 14 a$ and $J r P P O-1$ genes with denaturation at $94{ }^{\circ} \mathrm{C}$ for $1 \mathrm{~min}$, annealing at $60^{\circ} \mathrm{C}$ for $1 \mathrm{~min}$, and synthesis at $72^{\circ} \mathrm{C}$ for $1 \mathrm{~min}$ in 35 cycles with preheating at $90{ }^{\circ} \mathrm{C}$ for $5 \mathrm{~min}$ and final extension at $72{ }^{\circ} \mathrm{C}$ for $5 \mathrm{~min}$. The primer pairs were JrPPO-1-F (AACAGGATCTGCATTTTCATCA) and JrPPO-1-R (TTCTTTCCATTCCATCGCTACT), p14a-F (GAAGAACTCTTAGATAGGGACGTTGA) and P14a-R (TCTCTAGCAATTGTTTGTGTCGTAAG). Primers were designed according to JrPPO-1 gene sequences reported by Escobar et al. (2008). P14a gene sequences from tomato were aligned with walnut genome sequences (A.M. Dandekar, 
unpublished data), using BLAST to identify the walnut version of the tomato P14a.

REAL-Time PCR. Three replicates of whole leaf samples detached at $0,24,72,96,120$, and $144 \mathrm{~h}$ after inoculation with Xaj 417 were stored at $-80{ }^{\circ} \mathrm{C}$. Total RNA was isolated using PureLink Plant RNA Reagent (Ambion, Carlsbad, CA) and purified using RNeasy MiniElute Cleanup Kit (Qiagen). The concentration and quality of extracted RNA was determined by spectrophotometric analysis and electrophoretic separation using an Experion Automated Electrophoresis System (Bio-Rad, Hercules, CA). The cDNA synthesis was carried out using QuantiTect ${ }^{\circledR}$ Reverse Transcription Kit (Qiagen). To analyze the response of $J r P P O-1$ and $P 14 a$ to $X a j 417$, quantitative realtime RT-PCR (qPCR) was conducted using $\mathrm{iTaq}^{\mathrm{TM}}$ Universal SYBR ${ }^{\circledR}$ Green Supermix Kit (Step one ${ }^{T M}$ Real-Time PCR System; Applied Biosystems, Foster City, CA). The primers PPO1-F (CTAAAGACCAAGCCGACACC), PPO1-R (TCTTCCTCGTCGTCCTTTTC) and P14a-F (CATCGCACTTTAGCACAC), P14a-R (GTGGGTGGCAGAGAAGC) were used for JrPPO-1 and $P 14 a$ transcript analyses. Primers for the $18 \mathrm{~S}$ ribosomal RNA (rRNA) transcript, which was used as a reference gene (Kim et al., 2004), include 18S rRNA-F (AGAGGCCTACAATGGTGGTG) and 18S rRNA-R (CTCCAATGGATCCTCGTTA). The $\Delta \Delta \mathrm{Ct}\left(2^{\Delta \Delta \mathrm{Ct}}\right)$ method was applied to analyze relative differences in gene expression among samples (Livak and Schmittgen, 2001).

Statistical Analysis. Statistical analysis was performed using one-way analysis of variance (ANOVA). Values for $P<$ 0.05 were considered statistically significant.

\section{Results}

Blight symptoms appeared on the inoculated leaf tissue in 'Serr' and 'Chandler' $96 \mathrm{~h}$ after inoculation. Results of PPO activity assays showed that the PPO activity in these cultivars was strongly induced, beginning at $24 \mathrm{~h}$ after inoculation (Fig. 1), and an increase in PPO activity was observed in both cultivars tested. The increase in 'Chandler' was close to 2-fold greater than in 'Serr' (Fig. 1). Presence of the $P 14 a$ and JrPPO-1 genes in both 'Serr' and 'Chandler' was demonstrated using standard PCR to amplify $0.5-\mathrm{kb}$ fragments from genomic DNA (Fig. 2).

Results showed highly significant increases in $J r P P O-1$ gene expression at $24 \mathrm{~h}$ for both cultivars. Expression was 4-fold greater in 'Serr' than in 'Chandler' at $24 \mathrm{~h}$ and 7-fold greater at $72 \mathrm{~h}$. Differences between cultivars were significant at both periods $[P<0.05$ (Fig. 3)]. Subsequent expression at 96, 120 , and $144 \mathrm{~h}$ was generally not greater than in the control. The

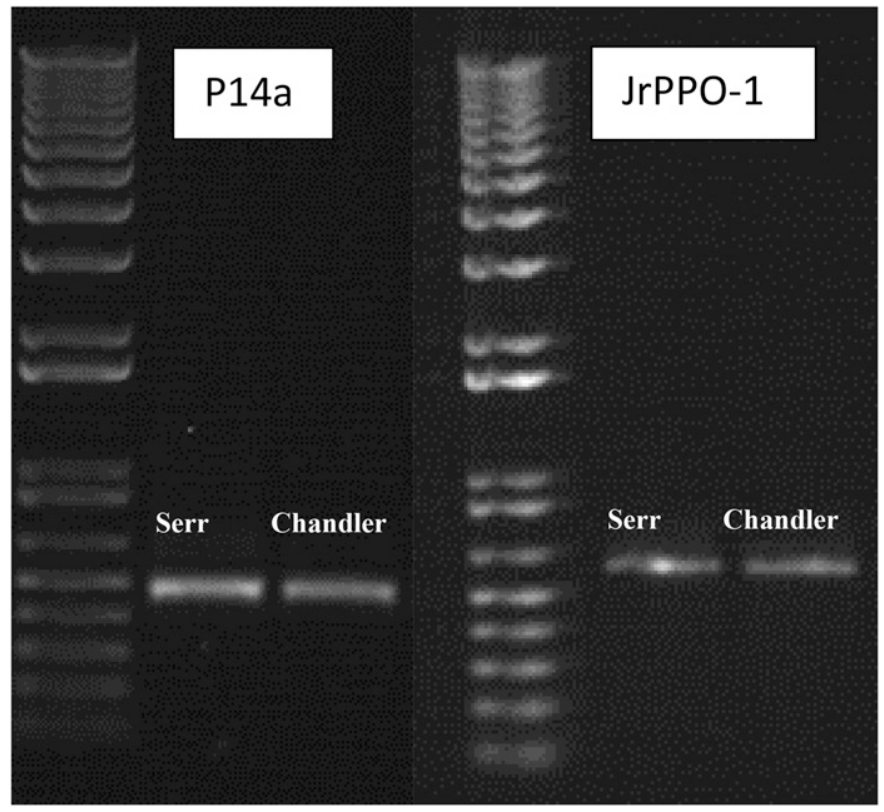

Fig. 2. Gel electrophoresis separation of polymerase chain reaction (PCR) products obtained using P14a and JrPPO primers and DNA extracted from two walnut cultivars, Serr and Chandler. PCR products sizes were 500 and 598 $\mathrm{bp}$, respectively.

greatest upregulation of $\mathrm{JrPPO}-1$ gene expression was observed in leaves of 'Chandler' and 'Serr' at 24 and $72 \mathrm{~h}$ after inoculation (Fig. 3).

A marked rise in P14a gene expression in response to the Xaj 417 was observed within $24 \mathrm{~h}$ in both cultivars but expression in the two cultivars differed sharply (Fig. 4). 


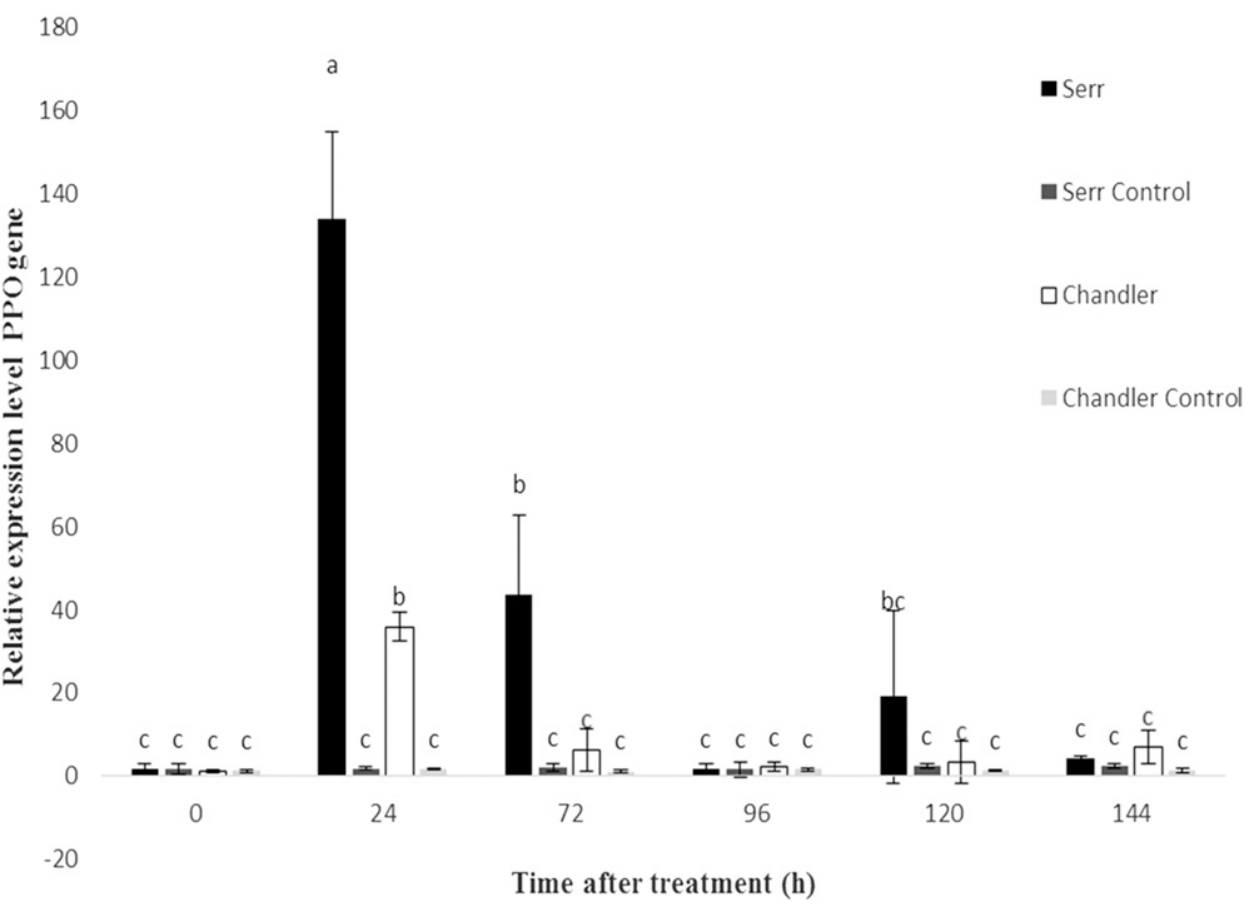

Fig. 3. The polyphenol oxidase gene expression induced by Xanthomonas arboricola pv. juglandis 417 in walnut leaves at $0,24,72,96,120$, and $144 \mathrm{~h}$ and normalized with respect to the expression of the $18 \mathrm{~S}$ RNA encoding reference gene (method of $2^{\Delta \Delta \mathrm{Ct}}$ ).

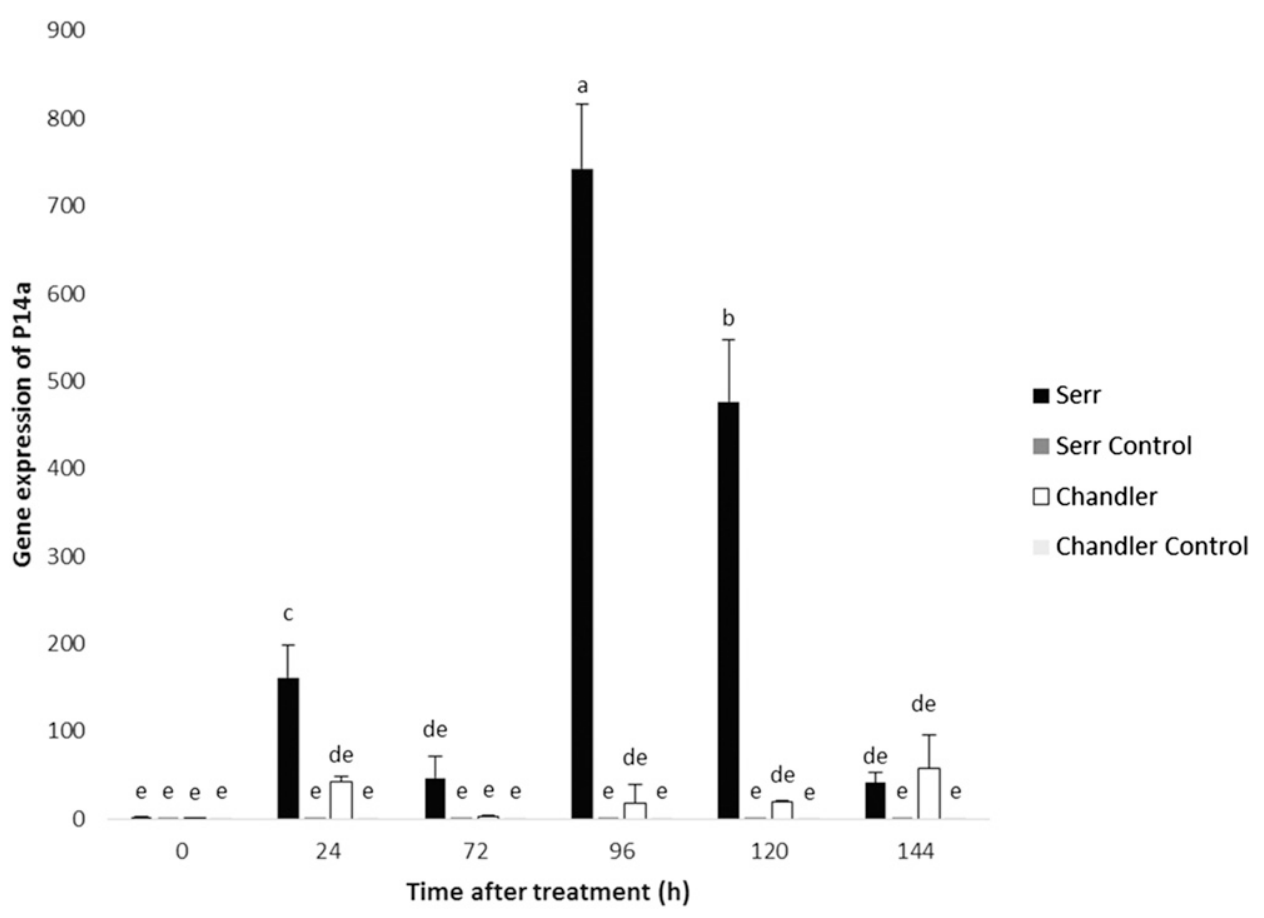

Fig. 4. P14a gene expression in walnut leaves induced by Xanthomonas arboricola pv. juglandis at 0, 24, 72, 96, 120 , and $144 \mathrm{~h}$ and normalized with respect to the expression of the $18 \mathrm{~S}$ RNA reference gene in the walnut (method of $2^{\Delta \Delta \mathrm{Ct}}$ ).

Expression remained relatively low in 'Chandler' throughout the $144 \mathrm{~h}$ time course but, after an initial period of moderate response, $P 14 a$ gene expression in 'Serr' rose sharply at $96 \mathrm{~h}$ and remained high at $120 \mathrm{~h}$ before dropping to near initial levels at $144 \mathrm{~h}$ (Fig. 4).

\section{Discussion}

In this study, we examined the regulation of PPO and $P 14 a$ genes by measuring the enzymatic activity of PPO and mRNA levels of $J r P P O-1$ and $P 14 a$ genes during the infection of 'Serr' and 'Chandler' walnut leaves by the blight pathogen $X a j$ 417. Strong induction of PPO has been reported in diverse plant species after wounding, application of MeJA (Constabel and Ryan, 1998), or inoculation with pathogens (Constabel et al., 1995; Sarwar et al., 2003; Thipyapong et al., 1995). Enhanced activation of PPO was evident in sunflower (Helianthus annuus) at $12 \mathrm{~h}$ after inoculation of plant growthpromoting rhizobacteria to induce resistance to Plasmopara halstedii (Nandeeshkumar et al., 2008). Moreover, in this study, presence of the $J r P P O-1$ gene in 'Chandler' was detected, which is in agreement with previous work by Escobar et al. (2008). PPO enzymatic activity and mRNA abundances, as analyzed using qPCR, showed upregulation of the JrPPO-1 gene within $24 \mathrm{~h}$ of exposure of walnut leaves to $X a j$ 417. The PPO enzymatic activity induced by Xaj 417 increased steadily during the incubation period after inoculation. The two cultivars differed in both degree of gene expression and level of enzymatic activity. PPO activity in response to $X a j$ was greater in 'Chandler' than in 'Serr' but PPO gene expression was stimulated most strongly in 'Serr'. The observed sharp rise in PPO expression in both cultivars within $24 \mathrm{~h}$ after inoculation might indicate an immediate response to the pathogen by rapid synthesis of antimicrobials to ward off attack. Finding a straight relationship between protein and mRNA levels can be challenging, and previous efforts to find correlations have found variable achievement. The individual half-life of proteins is the main posttranslational factor influencing mRNAprotein correlation. Furthermore, there might be differences in their ability to be translated into protein or in the processing steps that precede the enzyme activity (Maier et al., 2009). There could also be additional unidentified PPO gene activity that we are measuring enzymatically. This disconformity between PPO gene expression 
and enzymatic activity has been previously observed (Webb et al., 2013).

A variety of pathogens including viruses, fungi, and bacteria are known to induce PPO activity (Mayer, 2006). Significant increase in PPO activity resulting from host-pathogen interactions also have been reported in tobacco [Nicotiana tabacum (Conti et al., 1982)], pepper [Capsicum annuum (Gentile et al., 1982)], and tomato (Lusia and Matta, 1989). In addition, PPO activity in response to wounding and MeJA exposure has been found in several plant species (Constabel and Ryan, 1998). PPO also has been shown in other plants to be induced by wounding, MeJa, systemin, and various pathogens (Constabel et al., 1995; Constabel and Ryan, 1998; Thipyapong, 1997).

The role of the dandelion (Taraxacum officinale) ToPPO-2 gene in dandelion's disease resistance was investigated by overexpression in Arabidopsis thaliana. That study also introduced the use of $A$. thaliana as a useful system for the study of expression of plant PPOs (Dirks et al., 2008). In addition, overexpression of a PPO gene in transgenic tomato plants resulted in enhanced bacterial disease resistance ( $\mathrm{Li}$ and Steffens, 2002). Thus, the increase in PPO activity and upregulation of the $J r P P O-1$ gene after inoculation of walnut leaves in our study is consistent with the expectations based on the inducible nature of PPO activity generally in response to pathogenesis (Constabel et al., 1995; Thipyapong, 1997). Further establishment and understanding of the relationship between increased PPO gene expression in walnut and response to bacterial blight caused by Xaj 417 can open new insights to evaluate the role of PPO in defense against walnut blight and provide paths to selecting or enhancing resistance to this important pathogen.

The P14a gene was induced strongly in leaves of the cultivar Serr after $96 \mathrm{~h}$, coinciding with the onset of symptoms due to Xaj 417 infection. The level of P14a gene expression varied between cultivars and with time after pathogen exposure. Expression was much stronger in 'Serr' than in 'Chandler'. The mechanism of action related to the expression of $P 14 a$ gene expression in cultivar disease responses remains to be understood. Slight upregulation of PRI has also been reported in tomato cells inoculated with Fusarium oxysporum f. sp. lycopersici (Aimé et al., 2008). Generally, in plant-pathogen interactions, plant response genes are activated.

Several studies have shown that some PR proteins are involved in specific defense responses against particular pathogens while other products of these PR families are involved in inducible and nonspecific defense response to pathogens (Krebs and Grumet, 1993; Rep et al., 2002; van Pelt-Heerschap and Smit-Bakker, 1999). In a study of the expression of PR protein in two wheat cultivars, the PR protein gene was regulated in both susceptible and tolerant cultivars (Bajestani et al., 2012). The upregulation of a $P R 1$ gene family in rice-blast fungus (Magnaporthe grisea) interaction was determined, and a pathogenrelated role of these genes was established (Mitsuhara et al., 2008). Moreover, a high level of $P 14 a$ was observed in tomato susceptible to yellow leaf curl virus (Adi et al., 2012). Considering the role of PR genes generally, as described in these studies, our results suggest further exploration of a pathogen defense-related role for the P14a gene in walnut, particularly in the walnut-Xaj interaction. These results regarding P14a expression in walnut are preliminary but show the response in two cultivars of walnut in relation to bacterial blight infection.
In this study, inducible ability of the JrPPO- 1 and $P 14 a$ genes in walnut after inoculation with $X a j 417$ was determined. In addition, an increase in PPO activity in the inoculated leaves was detected. The role of PPO and P14a gene expression in walnut needs further investigation but this work shows that both genes are inducible during walnut-bacterial blight interaction. We report the time course changes in PPO enzymatic activity and in expression of genes encoding both $\mathrm{JrPPO}-1$ and $\mathrm{P14a}$ following $X a j 417$ infection and found that the two walnut cultivars examined differed in their responses. Further studies are required to determine the underlying mechanism by which PPO provides a defense either directly or in combination with other features of the plant defense response that include P14a and other PR proteins.

\section{Literature Cited}

Adi, M., P. Jens, Y. Brotman, K. Mikhail, S. Iris, C. Henryk, and G. Rena. 2012. Stress responses to tomato yellow leaf curl virus (TYLCV) infection of resistant and susceptible tomato plants are different. Metabolomics, doi: 10.4172/2153-0769.S1-006.

Aimé, S., C. Cordier, C. Alabouvette, and C. Olivain. 2008. Comparative analysis of PR gene expression in tomato inoculated with virulent Fusarium oxysporum f. sp. lycopersici and the biocontrol strain F. oxysporum Fo47. Physiol. Mol. Plant Pathol. 73:9-15.

Aleta, N., A. Ninot, C. Moragrega, I. Liorente, and E. Montesinos. 2001. Blight sensitivity of Spanish selections of Juglans regia. Acta Hort. 544:353-362.

Alexander, D., R.M. Goodman, M. Gut-Rella, C. Glascock, K. Weymann, L. Friedrich, D. Maddox, P. Ahl-Goy, T. Luntz, E. Ward, and J. Ryals. 1993. Increased tolerance to two oomycete pathogens in transgenic tobacco expressing pathogenesis-related protein 1a. Proc. Natl. Acad. Sci. USA 90:7327-7331.

Araji, S., A. Theresa, R.G. Gertzen, S.D. Anderson, M. MikulicPetkovsek, R. Veberic, M.L. Phu, A. Solar, C.A. Leslie, A.M. Dandekar, and M.A. Escobar. 2014. Novel roles for the polyphenol oxidase enzyme in secondary metabolism and the regulation of cell death in walnut. Plant Physiol. 164:1191-1203.

Arpita, S., D. Subroto, B. Pinaki, and B. Bidyut. 2010. Inhibition of polyphenol oxidase in banana, apple and mushroom by using different anti-browning agents under different conditions. Intl. J. Chem. Sci. 8:S550-S558.

Bajestani, F.B., S.S. Ramezanpour, H. Soltanloo, S. Navabpour, and S.V. Bastam. 2012. Induced acidic chitinase expression and scabresistant in wheat under field condition. J. Sci. Islamic Republic Iran 23:205-211.

Bradford, M.M. 1976. Rapid and sensitive method for quantitation of microgram quantities of protein utilizing the principle of protein-dye binding. Anal. Biochem. 72:248-254.

Camacho Henriquez, A. and H.L. Sanger. 1982. Analysis of acidextractable tomato leaf proteins after infection with a viroid, two viruses and a fungus and partial purification of the 'pathogenesisrelated' protein P14. Arch. Virol. 74:181-196.

Colaric, M., R. Veberic, A. Solar, M. Hudina, and F. Stampar. 2005. Phenolic acids, syringaldehyde, and juglone in fruits of different cultivars of Juglans regia L. J. Agr. Food Chem. 53:6390-6396.

Constabel, C.P., D.R. Bergey, and C.A. Ryan. 1995. Systemin activates synthesis of wound-inducible tomato leaf polyphenol oxidase via the octadecanoid defense signaling pathway. Proc. Natl. Acad. Sci. USA 92:407-411.

Constabel, C.P. and C.A. Ryan. 1998. A survey of wound- and methyl jasmonate-induced leaf polyphenol oxidase in crop plants. Phytochemistry 47:507-511.

Conti, G.G., A.M. Bocci, and M.T. Sprocati. 1982. Peroxidase and polyphenoloxidase isoenzymes, hypersensitive reaction and systemic induced resistance in Nicotiana glutinosa L. infected with tobacco mosaic virus. Rivista DI Patologia Vegetale 18:83-102. 
Dirks, M.E., C. Richter, and B.M. Moerschbacher. 2008. Heterologous expression of an infection-induced dandelion (Taraxacum officinale) polyphenol oxidase affects disease resistance of Arabidopsis thaliana. J. Plant Dis. Prot. 115:139-143.

Escobar, M.A., A. Shilling, P. Higgins, S.L. Uratsu, and A.M. Dandekar. 2008. Characterization of polyphenol oxidase from walnut. J. Amer. Soc. Hort. Sci. 133:852-858.

Garcin, A. and D. Duchesne. 2001. Walnut blight and apical necrosis. Acta Hort. 544:379-387.

Gentile, I.A., M. Coghe, and A. Matta. 1982. Phenols, polyphenol oxidase and peroxidase in pepper plants infected by virulent and avirulent strains of Verticillium. Rivista di Patologia Vegetale 18:5-12.

Heath, M.C. 2000. Hypersensitive response-related death. Plant Mol. Biol. 44:321-334.

Jacobson, E.S. 2000. Pathogenic roles for fungal melanins. Clin. Microbiol. Rev. 13:708-717.

Kim, B-R., H-Y. Nam, S-I. Kim, and Y.J. Chang. 2004. Normalization of reverse transcription quantitative-PCR with housekeeping genes in rice. Biotechnol. Lett. 25:1869-1872.

Krebs, S.L. and R. Grumet. 1993. Characterization of celery hydrolytic enzymes induced in response to infection by Fusarium oxysporum. Physiol. Mol. Plant Pathol. 43:193-208.

Li, L. and J.C. Steffens. 2002. Over-expression of polyphenol oxidase in transgenic tomato plants results in enhanced bacterial disease resistance. Planta 215:239-247.

Livak, K.J. and T.D. Schmittgen. 2001. Analysis of relative gene expression data using real-time quantitative PCR and the $2^{-\Delta \Delta} \mathrm{Ct}$ method. Methods 25:402-408.

Lusia, D.V. and A. Matta. 1989. An ultrastructural and cytochemical study of peroxidases, polyphenol oxidases and phenols in xylem of tomato plants infected with Fusarium oxysporum f. sp. lycopersici or F. oxysporum f. sp. melonis. Caryologia 42:103-114.

Maier, T., M. Güell, and L. Serrano. 2009. Correlation of mRNA and protein in complex biological samples. FEBS Lett. 583:3966-3973. Mayer, A.M. 2006. Polyphenol oxidases in plants and fungi: Going places? A review. Phytochemistry 67:2318-2331.

Mesquita, V.L.V. and C. Queiroz. 2013. Enzymatic browning, p. 387418. In: N. Eskin and F. Shahidi (eds.). Biochemistry of foods. Academic Press, London, UK.

Mitsuhara, I., T. Iwai, S.H. Seo, Y. Yanagawa, H. Kawahigasi, S. Hirose, Y. Ohkawa, and Y. Ohashi. 2008. Characteristic expression of twelve rice PR1 family genes in response to pathogen infection, wounding, and defense-related signal compounds (121/180). Mol. Genet. Genomics 279:415-427.

Mueller, L.A., U. Hinz, M. Uze, C. Sautter, and J.P. Zryd. 1997. Biochemical complementation of the betalain biosynthetic pathway in Portulaca grandiflora by a fungal 3,4-dihydroxy-phenyl-alanine dioxygenase. Planta 203:260-263.

Nandeeshkumar, P., K. Ramachandrakini, H.S. Prakash, S.R. Niranjana, and H. Shekar Shetty. 2008. Induction of resistance against downy mildew on sunflower by rhizobacteria. J. Plant Interact. 3:255-262.

Pereira, U.P., H. Gouran, R. Nascimento, J.E. Adaskaveg, L.R. Goulart, and A.M. Dandekar. 2015. Complete genome sequence of Xanthomonas arboricola pv. juglandis 417, a copper-resistant strain isolated from Juglans regia L. Genome Announc. 3(5):e01126-e15. Radix, P., C. Bastien, C. Jay-Allemand, G. Charlot, and F. Seigle-Murandi. 1998. The influence of soil nature on polyphenols in walnut tissues: A possible explanation of differences in the expression of walnut blight. Agronomie 18:627-637.

Raj, S.N., B.R. Sarosh, and H.S. Shetty. 2006. Induction and accumulation of polyphenol oxidase activities as implicated in development of resistance against pearl millet downy mildew disease. Funct. Plant Biol. 33:563-571.

Rep, M., H.L. Dekker, J.H. Vossen, A.D. de Boer, P.M. Houterman, and D. Speijer. 2002. Mass spectrometric identification of isoforms of PR proteins in xylem sap of fungus-infected tomato. Plant Physiol. 130:904-917.

Ryals, J.A., U.H. Neuenschwander, M.G. Willits, A. Molina, H.Y. Steiner, and M.D. Hunt. 1996. Systemic acquired resistance. Plant Cell 8:1809-1819.
Sarwar, N., M. Sarwar, and F.F. Jamil. 2003. Role of polyphenoloxidase and catalase in Ascochyta blight resistance in chickpea. Pak. J. Bot. 35:111-115.

Solar, A., M. Colaric, V. Usenik, and F. Stampar. 2006. Seasonal variations of selected flavonoids, phenolic acids and quinones in annual shoots of common walnut (Juglans regia L.). Plant Sci. 170:453-461.

Soler-Rivas, C., A.C. Moller, N. Arpin, J.M. Olivier, and H.J. Wichers. 2000. Induction of tyrosinase mRNA in Agaricus bisporus upon treatment with a tolaasin preparation from Pseudomonas tolaasii. Physiol. Mol. Plant Pathol. 58:95-99.

Steffens, J.C., E. Harel, and M.D. Hunt. 1994. Polyphenol oxidase, p. 275-312. In: B.E. Ellis (ed.). Genetic engineering of plant secondary metabolism. Plenum Press, New York, NY.

Steiner, U., W. Schlieman, H. Bohm, and D. Strack. 1999. Tyrosinase involved in betalain biosynthesis of higher plants. Planta 208:114124.

Strack, D., T. Vogt, and W. Schliemann. 2003. Recent advances in betalain research. Phytochemistry 62:247-269.

Teviotdale, B.L., M.N. Schroth, and E.M. Mulrean. 1985. Bark, fruit and foliage diseases, p. 153-157. In: D. Ramos (ed.). Walnut orchard management. Univ. California, Div. Agr. Natural Resources, Publ. 21410.

Thaler, J.S., A.L. Fidantsef, S.S. Duffey, and R.M. Bostock. 1999. Trade-offs in plant defense against pathogens and herbivores: A field demonstration of chemical elicitors of induced resistance. J. Chem. Ecol. 25:1597-1609.

Thipyapong, P. 1997. Polyphenol oxidase gene family: Differential expression during vegetative and reproductive development, and in response to injuries and defensive functional analysis. $\mathrm{PhD}$ Diss., Cornell Univ., Ithaca, NY.

Thipyapong, P., M.D. Hunt, and J.C. Steffens. 1995. Systemic wound induction of potato (Solanum tuberosum) polyphenol oxidase. Phytochemistry 40:673-676.

Thipyapong, P., M.D. Hunt, and J.C. Steffens. 2004. Antisense down regulation of polyphenol oxidase results in enhanced disease susceptibility. Planta 220:105-107.

Topp, B.L., W.B. Sherman, R.E. Stall, G.V. Minsavage, and C.J. Wilcox. 1993. Comparison of greenhouse methods for assessing resistance to bacterial leaf spot in plum. J. Amer. Soc. Hort. Sci. 118:667-671.

van Loon, L.C. and E.A. van Strien. 1999. The families of pathogenesisrelated proteins, their activities, and comparative analysis of PR-1 type proteins. Physiol. Mol. Plant Pathol. 55:85-97.

van Pelt-Heerschap, H. and O. Smit-Bakker. 1999. Analysis of defense-related proteins in stem tissue of carnation inoculated with a virulent race of Fusarium oxysporum f. sp. dianthi. Eur. J. Plant Pathol. 105:681-691.

Walker, J.R.L. 1995. Enzymatic browning in fruits, p. 8-22. In: C.Y. Lee and J.R. Whitaker (eds.). Enzymatic browning and its prevention. Amer. Chem. Soc., Washington, DC.

Wang, J. and C.P. Constabel. 2004a. Polyphenol oxidase overexpression in transgenic Populus enhances resistance to herbivory by forest tent caterpillar (Malacosoma disstria). Planta 220:87-96.

Wang, J. and C.P. Constabel. 2004b. Three polyphenol oxidases from hybrid poplar are differentially expressed during development and after wounding and elicitor treatment. Physiol. Plant. 122:344-353.

Ward, E.R., S.J. Uknes, S.C. Williams, S.S. Dincher, D.L. Wiederhold, D.C. Alexander, P. Ahl-Goy, J.P. Metraux, and J.A. Ryals. 1991. Coordinate gene activity in response to agents that induce systemic acquired resistance. Plant Cell 3:1085-1094.

Webb, K.J., A. Cookson, G. Allison, M.L. Sullivan, and A.L. Winters. 2013. Gene expression patterns, localization, and substrates of polyphenol oxidase in red clover (Trifolium pratense L.). J. Agr. Food Chem. 61:7421-7434.

Woeste, K.E., G.H. McGranahan, and M.N. Schroth. 1992. Variation among persian walnuts in response to inoculation with Xanthomonas campestris pv. juglandis. J. Amer. Soc. Hort. Sci. 117:527-531. 